\title{
Perceived Risks; Prominent Dimensions among Tourists from South India
}

Jose K Antony*

\section{Abstract}

Making travel decisions is never an easy task as tourists will have to consider numerous factors revolving around time, finance, transportation, destinations and activities. Travel decisions are normally made with no expectation of any kind of economic or material returns; intangible results such as pleasure and satisfaction are expected. Therefore, the tourist consumption behavior will involve elements of risk taking. Actions of tourists will regularly yield results and consequences that they may not always be able to anticipate with any approximating degree of certainty, and some of these are at least likely to turn unpleasant. Today, tourists are rarely in a state of mind to anticipate the exact probabilities or risks associated with their purchases. Numerous dimensions of perceived risk have already been identified, such as risks associated with Age, Gender, Income, Personality, Satisfaction, Past Experience, Culture, Nationality and Destination Image. Some of these dimensions appeared more prominent than the others, namely Health Risk, Financial Risk, Time Risk, Safety and Security Risk, and Information and Communication Risk. Research on perceived risk related to tourism has most often been neglected, and in-depth studies on the same have not been extensively undertaken, especially on the South Indian tourists. In

Assistant Professor, School of Business Studies and Social Sciences, Christ University, Bengaluru, India; jose.antony@christuniversity.in 
this context, the study proposes to investigate the risk perception of tourists travelling from South India.

Keywords: Perceived Risk, Health Risk, Financial Risk, Time Risk, Safety and Security Risk, Information and Communication Risk

\section{Introduction}

Tourists are rational decision-makers and they will always try to maximise utilities by assessing the costs and benefits of their actions, before committing themselves to any purchase. Tourism purchase decisions, but are not devoid of risks as they require extensive problem solving and advance planning. Therefore, it is most common that every potential tourist faces a certain level of risk whenever they travel. This is mainly due to the intangible nature of travel services. This intangible character makes it necessary for the consumption of the tourism services simultaneously along with production.

'Risk' is most often expressed as the chance that an event may occur. The concept of perceived risk has been widely employed in the study of Consumer Behavior in the area of Marketing. Perceived risk in Marketing is usually defined as the level of uncertainty that consumers may encounter when they are not able to foresee the after effects of their purchase decisions. Actions of consumers may regularly yield results that they will not be able to anticipate with an approximating degree of certainty, and many a times, some of these actions may even turn unpleasant.

Today with the number of choices available, consumers are rarely in a state of mind to anticipate the exact probabilities associated with their purchases. Furthermore, consumers in the Tourism Industry are found to make travel choices expecting intangible results, such as pleasure and satisfaction, thus increasing their level of risk. Perceived risks and their impact on travel activities is an area of research that has most often been neglected. In-depth studies on the influence of the perceived risks have not been extensively undertaken, especially in the South Indian context. 
The study proposes to identify and investigate the various dimensions of perceived risks associated with tourists travelling from South India. Few dimensions of perceived risks such as Communication Risk, Equipment Risk, Financial Risk, Health Risk, Satisfaction Risk, Social Risk, Terrorism Risk, Time Risk, Physical Risk, Political Instability Risk and Psychological Risk were identified through intense reviews of literature. Few of the dimensions were employed in the study.

\section{Review of Literature}

'Risk' is often expressed as the chance that an event may occur. However, the definition of risk remained non-standardized. A study by Schiffman and Kanuk in 2000suggesteda definition for perceived risk as the level of uncertainty that consumers could face when they were not able to foresee the after effects of their purchase decisions. The definition also highlighted relevant dimensions of perceived risk namely the dimensions of uncertainty and outcome. Yates and Stone in 1992 had offered three different views on risk namely, that the risk construct was made up of several individual risk elements, the risk might involve several different and distinct elements, and risks might unfold in many different ways during varied situations and events.

Numerous research studies on Consumer Behavior have also identified and evaluated various risk perception construct elements. Brooker in 1984, Szybillo, Kaplan and Jacoby in 1972 and 1974, Ryan and Peter in 1976, Greatorex and Mitchell in 1990, Gronhaug and Stone in 1993, and Laroche Mc Dougall and Yang in 2004 were instrumental in studying risk perception as one of the most prominent and powerful factors in dissecting consumer behavior.

Jacoby and Kaplan in 1972 were the first to operationalize the construct of perceived risk. Through their study, they identified five important dimensions of risk namely financial, psychological, performance, physical and social risks. Their study identified that of all the dimensions; performance risk had the highest degree of correlation between all the perception factors of risk followed by financial risk. Financial risk was more prominent when it came to 
dealing with tangible products. Performance risk was also found to be more predictive out of all the factors that influenced the overall perception of risk. The study also found that the most influential form of risk was performance risk, among all the factors that influenced the overall risk perception for products.

The dimensions were later adopted by numerous other research studies (Cheron \& Ritchie, 1982; Mitra, Reiss, \& Capella, 1999; Stone \& Gronhaug, 1993; Stone \& Mason, 1995). Roselius in 1971 added the dimension of 'Time Risk'. Many studies investigated the six dimensions together (Stone \& Gronhaug, 1993; Stone \& Mason, 1995). The dimension of 'Risk of Satisfaction' was first encountered in a study on risk perception and leisure activities (Cheron \& Ritchie, 1982). Whereas few studies were purely based on a single dimension, for example, 'Political Instability Risk'(McCleary\& Whitney, 1994; Seddighi, Nuttall, \& Theocharous, 2001; Sonmez \&Graefe, 1998), and 'Terrorism Risk' (Sonmez \& Graefe,1998).

Various studies over the years also identified and studied other dimensions and forms of perceived risk, especially the studies conducted by Roehl and Fesenmaier (1992) on pleasure travel, as well as studies by Lepp and Gibson (2003) and Sonmez and Graefe (1998) on international leisure travel. While Cheron and Ritchie (1982) suggested an influence of the concept of familiarity on perceived risk, Pinheyand Iverson (1994) suggested the differences in language ability to impact perceived risk. To add on, Yavas in 1987 suggested that differences in language also influenced destination choices.

Further, studies by Roehl and Fesenmaier (1992) and, Sonmez and Graefe (1998) added three other elements to risk namely, 'Health Risk', 'Political Instability Risk' and 'Terrorism Risk". The perception of falling ill, before, while travelling to or on reaching the destination constituted the Health Risk, the likelihood of encountering a political unrest or turmoil in the destination being visited constituted Political Instability Risk, and the chance of being associated with some form of a terrorist act formed a part of Terrorism Risk. 
Moutinho in 2000 was the first researcher to provide a comprehensive analysis of risk perceived with relation to tourist character. His simple take on perceived risk, to be a combination of consequences and uncertainty was found to be more generalized than the other definitions that were already studied and discussed. Uncertainties about the product, the place, the modes of purchase, uncertainties arising out of financial and psycho-social consequences, and the subjective uncertainties encountered by the tourists were the four views that were proposed through his study. Moutinho also examined the relationship between the risk perceptions elements, to more clearly understand the tourist's perception of risk involved in purchase decisions.

\section{Research Gap and Objective of the Study}

As read, some prominent studies have already been carried out on the impact of perceived risk on travellers. However, the numbers of research studies performed on the risk perception of tourists from South India have been limited. The present study aims to evaluate the risk perception of tourists from South India.

\section{Sample Size}

The investigation covered the metro cities in South India, namely Visakhapatnam in Telangana State, Hyderabad in Andhra, Bengaluru in Karnataka, Chennai in Tamil Nadu and Kochi in Kerala. The sample size for the survey was 500 and the respondents were selected using the Random Sampling Technique.

\section{Data Collection Sources and Methods}

The secondary data required for the study was derived from academic books, printed materials, newspapers, magazines, journals, articles, websites and related research articles, while the primary data was collected from the population and the sample group under the area of investigation.

Data was collected with the help of a scheduled questionnaire that was designed based on the objectives of the study and it was circulated among the respondents. The questionnaire included the respondents' demographic information, their travel information, experiences and perception of risks that they might encounter 
during their travel and holiday at the destination. Multiple choice, open-ended and rating using the Likert Five Point Rating Scale were used in the Questionnaire to elicit the required information. Factor Analysis as a Statistical tool and technique was then used to analyze the data from the questionnaire.

\section{Findings with the support of Data Analysis}

Assessing the Communalities through Factor Analysis

Table 1: Communalities

\begin{tabular}{|l|r|r|}
\hline Variables & Initial & Extraction \\
\hline $\begin{array}{l}\text { Choice of a holiday destination is influenced by } \\
\text { family and friends }\end{array}$ & 0.851 & 0.834 \\
\hline $\begin{array}{l}\text { Fear that family and friends may disapprove the } \\
\text { choice of a holiday destination }\end{array}$ & 0.850 & 0.793 \\
\hline $\begin{array}{l}\text { Holiday in a destination because everyone else goes } \\
\text { there }\end{array}$ & 0.739 & 0.720 \\
\hline $\begin{array}{l}\text { Thought that more time spend on a holiday will } \\
\text { make it more pleasurable and enjoyable }\end{array}$ & 0.640 & 0.596 \\
\hline $\begin{array}{l}\text { Fear of spending a lot of money on the holiday } \\
\text { Travel to holiday destinations to enhance self-image } \\
\text { among family and friends }\end{array}$ & 0.596 & 0.524 \\
\hline $\begin{array}{l}\text { Always look forward to enhancing feeling of well- } \\
\text { being during a holiday }\end{array}$ & 0.610 & 0.569 \\
\hline $\begin{array}{l}\text { Always make sure of comfort with the holiday } \\
\text { destination that is chosen }\end{array}$ & 0.727 & 0.627 \\
\hline $\begin{array}{l}\text { Never travel to a destination unless confident of the } \\
\text { safety of the destination }\end{array}$ & 0.535 & 0.807 \\
\hline $\begin{array}{l}\text { Do not mind travel to a destination that is politically } \\
\text { unstable }\end{array}$ & 0.525 & 0.549 \\
\hline $\begin{array}{l}\text { Local news about a destination influences holiday } \\
\text { there }\end{array}$ & 0.551 & 0.635 \\
\hline $\begin{array}{l}\text { Anxiety about safety and security always prevents } \\
\text { from taking risks during travel }\end{array}$ & 0.511 \\
\hline $\begin{array}{l}\text { Civil unrest demotivates from travelling to a } \\
\text { destination }\end{array}$ & $\begin{array}{l}\text { Concerned about language barriers when holidaying } \\
\text { in an unknown destination }\end{array}$ & 0.608 \\
\hline $\begin{array}{l}\text { Belief that knowledge in the English language will } \\
\text { help in communicating with different cultures }\end{array}$ & 0.441 \\
\hline
\end{tabular}




\begin{tabular}{|c|c|c|}
\hline $\begin{array}{l}\text { Assured of communicating confidently with anyone } \\
\text { during a holiday }\end{array}$ & 0.721 & 0.712 \\
\hline $\begin{array}{l}\text { Use of telecommunication devices during a holiday } \\
\text { is important }\end{array}$ & 0.752 & 0.795 \\
\hline $\begin{array}{l}\text { Always carry and use a smartphone during a } \\
\text { holiday }\end{array}$ & 0.731 & 0.752 \\
\hline Always carry heavy luggage during travel & 0.763 & 0.785 \\
\hline $\begin{array}{l}\text { Always afraid of losing/misplacing belongings } \\
\text { during travel }\end{array}$ & 0.704 & 0.715 \\
\hline $\begin{array}{l}\text { Never leave for a holiday without medicines and } \\
\text { first aid }\end{array}$ & 0.752 & 0.759 \\
\hline $\begin{array}{l}\text { Always afraid of falling sick from having local food } \\
\text { and water during travel }\end{array}$ & 0.823 & 0.834 \\
\hline $\begin{array}{l}\text { Always prefer the most comfortable mode of } \\
\text { transportation }\end{array}$ & 0.687 & 0.657 \\
\hline $\begin{array}{l}\text { Like to do activities during a holiday that are } \\
\text { frightening }\end{array}$ & 0.694 & 0.664 \\
\hline $\begin{array}{l}\text { Enjoy being a part of daring activities during a } \\
\text { holiday }\end{array}$ & 0.691 & 0.655 \\
\hline $\begin{array}{l}\text { Feels good and satisfied to be a little scared during a } \\
\text { holiday }\end{array}$ & 0.677 & 0.618 \\
\hline Enjoy experiencing surprises during a holiday & 0.739 & 0.659 \\
\hline Enjoy activities that offer thrills & 0.678 & 0.547 \\
\hline Always try to seek adventure during a holiday & 0.595 & 0.577 \\
\hline $\begin{array}{l}\text { Always try to explore new things in the holiday } \\
\text { destination }\end{array}$ & 0.660 & 0.656 \\
\hline $\begin{array}{l}\text { Always try to experience cultures and customs, very } \\
\text { different from own }\end{array}$ & 0.701 & 0.796 \\
\hline $\begin{array}{l}\text { Always look forward to a change in environment, } \\
\text { very different from own }\end{array}$ & 0.615 & 0.511 \\
\hline $\begin{array}{l}\text { Always want a sense of discovery to be part of the } \\
\text { holiday }\end{array}$ & 0.688 & 0.623 \\
\hline $\begin{array}{l}\text { Always read and study about the culture of the } \\
\text { destination that is planned to visit }\end{array}$ & 0.596 & 0.528 \\
\hline $\begin{array}{l}\text { Always look forward to interacting with the local } \\
\text { community during the holiday }\end{array}$ & 0.707 & 0.771 \\
\hline $\begin{array}{l}\text { Take a holiday from time to time as it helps to } \\
\text { unwind }\end{array}$ & 0.668 & 0.591 \\
\hline Enjoy travelling as the same routine work is boring & 0.654 & 0.544 \\
\hline $\begin{array}{l}\text { Never plan holidays in detail as it takes away some } \\
\text { of the unexpectedness in the destinations }\end{array}$ & 0.670 & 0.668 \\
\hline Enjoy holidays that are educational & 0.712 & 0.650 \\
\hline
\end{tabular}


Ideal holiday involves experiencing something totally new from what has already been experienced before

\section{Extraction Method: Principal Axis Factoring.}

From the Table of Communalities, it can be inferred that a total of $83.4 \%$ of the Variance in Influence of Family and Friends, and Fear of Local Food and Water is explained by the extracted factors.

At the same time, $30.3 \%$ of the Variance in Politically Unstable Destination is explained by the extracted factors, and therefore it can be dropped from the Analysis.

Through the Principal Axis Factoring Extraction Method, 11 Factors were identified. Table 2 explains the Total Variance of the Eigen Values of the identified 11 Factors.

Table 2: Total Variance Explained

\begin{tabular}{|l|r|r|r|r|r|r|}
\hline \multirow{2}{*}{ Factor } & \multicolumn{3}{|c|}{$\begin{array}{c}\text { Initial } \\
\text { Eigen values }\end{array}$} & \multicolumn{3}{c|}{$\begin{array}{c}\text { Extraction Sums of Squared } \\
\text { Loadings }\end{array}$} \\
\cline { 2 - 7 } & Total & $\begin{array}{c}\text { \% of } \\
\text { Variance }\end{array}$ & $\begin{array}{c}\text { Cumulative } \\
\%\end{array}$ & Total & $\begin{array}{c}\text { \% of } \\
\text { Variance }\end{array}$ & $\begin{array}{c}\text { Cumulative } \\
\%\end{array}$ \\
\hline 1 & 6.339 & 15.848 & 15.848 & 6.016 & 15.039 & 15.039 \\
\hline 2 & 4.791 & 11.976 & 27.825 & 4.438 & 11.096 & 26.135 \\
\hline 3 & 3.193 & 7.982 & 35.807 & 2.828 & 7.070 & 33.205 \\
\hline 4 & 2.780 & 6.951 & 42.757 & 2.498 & 6.245 & 39.449 \\
\hline 5 & 2.536 & 6.340 & 49.097 & 2.201 & 5.502 & 44.951 \\
\hline 6 & 2.218 & 5.546 & 54.643 & 1.872 & 4.680 & 49.632 \\
\hline 7 & 2.047 & 5.118 & 59.761 & 1.655 & 4.136 & 53.768 \\
\hline 8 & 1.683 & 4.208 & 63.969 & 1.372 & 3.430 & 57.199 \\
\hline 9 & 1.609 & 4.022 & 67.991 & 1.229 & 3.071 & 60.270 \\
\hline 10 & 1.244 & 3.111 & 71.102 & 0.858 & 2.145 & 62.415 \\
\hline 11 & 1.106 & 2.765 & 73.867 & 0.703 & 1.758 & 64.174 \\
\hline
\end{tabular}

Extraction Method: Principal Axis Factoring.

Further, using the Principal Axis Factoring Extraction Method, along with Varimax and Kaiser Normalization Rotation Method (converged in 9 iterations), the Variables are grouped under one of the 11 Factors based on their Loadings. 
Further are given, the Variables and the Factors towards which they are more closely loaded towards.

\section{Factor 1: Influence of Family and Friends}

Table 3: Influence of Family and Friends

\begin{tabular}{|l|c|}
\hline $\begin{array}{l}\text { Choice of a holiday destination is influenced by family and } \\
\text { friends }\end{array}$ & 0.813 \\
\hline $\begin{array}{l}\text { Afraid that family and friends may disapprove my choice of a } \\
\text { holiday destination }\end{array}$ & 0.864 \\
\hline Holiday in a destination because everyone else goes there & 0.834 \\
\hline $\begin{array}{l}\text { Think more time spend on a holiday will make it more } \\
\text { pleasurable and enjoyable }\end{array}$ & 0.629 \\
\hline $\begin{array}{l}\text { Afraid that I will end up spending a lot of money on my } \\
\text { holiday }\end{array}$ & 0.501 \\
\hline $\begin{array}{l}\text { Travel to holiday destinations that will enhance my self-image } \\
\text { among family and friends }\end{array}$ & 0.525 \\
\hline
\end{tabular}

It was found that Influence of Family and Friends has a profound impact on the choice of a Holiday Destination. Respondents feared that Family and Friends could disapprove of their Choice of a Holiday Destination (0.864); Respondents felt safe traveling to a Destination because everyone else went there (0.834) and they wanted to travel to a Holiday Destination to enhance their selfimage among their Family and Friends (0.525); Respondents were afraid that they might spend a lot of money during the holiday (0.501) but they also thought that more time spent on a holiday would make it more pleasurable and enjoyable (0.629).

\section{Factor 2: Thrilling Experience}

Table 4: Thrilling Experience

\begin{tabular}{|l|l|}
\hline Like to do activities during a holiday that are frightening & 0.554 \\
\hline Enjoy being a part of daring activities during a holiday & 0.760 \\
\hline Feel good and satisfied to be a little scared during a holiday & 0.771 \\
\hline Enjoy experiencing surprises during a holiday & 0.737 \\
\hline Enjoy activities that offer thrills & 0.643 \\
\hline Always try to seek adventure during a holiday trip & 0.603 \\
\hline
\end{tabular}

It was found that respondents looked forward to Thrilling Experiences during Holidays. The respondents felt good being a 
little scared during a Holiday (0.771); Respondents liked to do frightening (0.554), thrilling (0.643) and daring (0.760) activities during a Holiday; Respondents enjoyed experiencing surprises during the Holiday (0.737) and looked forward to seeking adventures during the Holiday Trip (0.603).

\section{Factor 3: Health Precautions}

Table 5: Health Precautions

\begin{tabular}{|l|c|}
\hline Never leave for a holiday without medicines and first aid & 0.845 \\
\hline $\begin{array}{l}\text { Always afraid of falling sick from having local food and water } \\
\text { during travel }\end{array}$ & 0.809 \\
\hline Always prefer the most comfortable mode of transportation & 0.761 \\
\hline
\end{tabular}

It was found that respondents took care of their Health during travel. They were always afraid of falling sick from having the Local Food and Water during travel (0.809) and therefore they never left for a Holiday without carrying their Medicines and First Aid (0.845); Respondents also preferred the most comfortable Mode of Transportation during a Holiday (0.761).

\section{Factor 4: New Experience}

Table 6: New Experience

\begin{tabular}{|l|c|}
\hline Enjoy travelling as the same routine work bores me & 0.673 \\
\hline $\begin{array}{l}\text { Never plan my holidays in detail as it takes away some of } \\
\text { the unexpectedness in the destinations }\end{array}$ & 0.768 \\
\hline Enjoy holidays that are educational & 0.665 \\
\hline $\begin{array}{l}\text { Ideal holiday involves experiencing something totally new } \\
\text { from what I have already experienced before }\end{array}$ & 0.754 \\
\hline
\end{tabular}

It was found that respondents always looked forward to experiencing something totally new during a holiday. Their ideal holiday involved experiences that were totally new from what they had already experienced before (0.754); Respondents did not like to plan their holidays in detail as it took away some of the unexpectedness in the destinations (0.768); They liked holidays which were educational $(0.665)$ as the same routine work bored them (0.673). 


\section{Factor 5: Learning and Involvement}

Table 7: Learning and Involvement

\begin{tabular}{|l|c|}
\hline Always want a sense of discovery to be part of my holiday & 0.683 \\
\hline $\begin{array}{l}\text { Always read and study about the culture of the destination that I } \\
\text { plan to visit }\end{array}$ & 0.679 \\
\hline $\begin{array}{l}\text { Always look forward to interacting with the local community } \\
\text { during the holiday }\end{array}$ & 0.778 \\
\hline Take a holiday from time to time as it helps me to unwind & 0.568 \\
\hline
\end{tabular}

It was found that respondents looked forward to Learning and Involvement during a Holiday. They were interested in interacting with the local community during the holiday (0.778); Respondents spend time reading and studying about the culture of the destination that they planned to visit (0.679); They wanted a sense of discovery to be part of their holiday (0.683) and they liked to take a holiday from time to time as it helped them to unwind (0.568).

\section{Factor 6: Confidence in Communication}

Table 8: Confidence in Communication

\begin{tabular}{|l|c|}
\hline $\begin{array}{l}\text { Believe my knowledge in the English language will help me in } \\
\text { communicating with different cultures }\end{array}$ & 0.566 \\
\hline $\begin{array}{l}\text { Assured of communicating confidently with anyone during a } \\
\text { holiday }\end{array}$ & 0.776 \\
\hline $\begin{array}{l}\text { Use of telecommunication devices during my holiday is } \\
\text { important }\end{array}$ & 0.801 \\
\hline Always carry and use mysmartphone during a holiday & 0.521 \\
\hline
\end{tabular}

It was found that Confidence in Communicating in the Destination was another important factor that influenced Choice of a Destination. Respondents were assured of communicating confidently with anyone during a holiday (0.776); Respondents felt it important to use telecommunication devices during a holiday (0.801) and they preferred to always carry and use their smartphones during a holiday (0.521). Respondents also felt that their knowledge in the English language would help them in communicating with different cultures (0.566). 


\section{Factor 7: Safety of Belongings}

Table 9: Safety of Belongings

\begin{tabular}{|l|c|}
\hline Always carry heavy luggage during travel & 0.868 \\
\hline $\begin{array}{l}\text { Always afraid of losing/misplacing my belongings during } \\
\text { travel }\end{array}$ & 0.824 \\
\hline
\end{tabular}

It was found that respondents were concerned about the Safety of their Belongings during travel. Respondents always preferred carrying heavy luggage during travel $(0.868)$ and they were always afraid of losing or misplacing their belongings during travel (0.824).

\section{Factor 8: Exploring New Things}

Table 10: Exploring New Things

\begin{tabular}{|l|c|}
\hline Always try to explore new things in the holiday destination & 0.750 \\
\hline $\begin{array}{l}\text { Always try to experience cultures and customs very different } \\
\text { from my own }\end{array}$ & 0.832 \\
\hline $\begin{array}{l}\text { Always look forward to a change in environment, very } \\
\text { different from my own }\end{array}$ & 0.558 \\
\hline
\end{tabular}

It was found that respondents looked forward to exploring new things during travel. During a holiday, they always try to experience cultures and customs very different from their own (0.832) and they always try to explore new things in the holiday destination (0.750). During the holiday, respondents look forward to a change in anenvironment very different from their own (0.558).

\section{Factor 9: Comfort and Well-Being}

Table 11: Comfort and Well-Being

\begin{tabular}{|l|c|}
\hline $\begin{array}{l}\text { Always look forward to enhancing my feeling of well-being } \\
\text { during a holiday }\end{array}$ & 0.694 \\
\hline $\begin{array}{l}\text { Always make sure that I am comfortable with the holiday } \\
\text { destination that I choose }\end{array}$ & 0.788 \\
\hline $\begin{array}{l}\text { Never travel to a destination unless I am confident of the } \\
\text { safety of the destination }\end{array}$ & 0.649 \\
\hline
\end{tabular}

It was found that Comfort and Well-Being in the Destination was another factor that influenced Destination Choice. Respondents always made sure that they were comfortable with the holiday 
destinations that they chose (0.788) and they always looked forward to enhancing their feeling of well-being during a holiday (0.694). The respondents did not travel to a destination unless they were confident about the safety of the destination (0.649).

\section{Factor 10: Safety and Security in the Destination}

Table 12: Safety and Security in the Destination

\begin{tabular}{|l|c|}
\hline Do not mind travel to a destination that is politically unstable & 0.402 \\
\hline Local news about a destination influences my holiday there & 0.702 \\
\hline $\begin{array}{l}\text { Anxiety about my safety and security always prevents me } \\
\text { from taking risks during travel }\end{array}$ & 0.745 \\
\hline Civil unrest de-motivates me from travelling to a destination & 0.488 \\
\hline
\end{tabular}

It was found that Safety and Security of the respondents also influenced their choice of a holiday destination. Anxiety about Safety and Security always prevented the respondents from taking risks during travel (0.745), and local news about a destination influenced their holidays there (0.702). Civil unrest demotivated the respondents from travelling to a destination (0.488), but the respondents did not mind travelling to a destination that was politically unstable (0.402).

\section{Factor 11: Fear of Language}

Table 13: Fear of Language

Concerned about language barriers when holidaying in an

unknown destination

It was found that respondents were concerned about language barriers when holidaying in an unknown destination (0.554).

Comparing the Mean Value of each Variable under each Factor, and ranking the Factors based on the Mean Value of their Variables, the following two tables were obtained. 
Table 14: Mean Value of Factor Variables

\begin{tabular}{|l|l|c|}
\hline Factor & Factor Name & Mean Value \\
\hline Factor 1 & Influence of Family and Friends & 0.694 \\
\hline Factor 2 & Thrilling Experience & 0.678 \\
\hline Factor 3 & Health Precautions & 0.805 \\
\hline Factor 4 & New Experience & 0.715 \\
\hline Factor 5 & Learning and Involvement & 0.677 \\
\hline Factor 6 & Confidence in Communication & 0.666 \\
\hline Factor 7 & Safety of Belongings & 0.846 \\
\hline Factor 8 & Exploring New Things & 0.713 \\
\hline Factor 9 & Comfort and Well-Being & 0.710 \\
\hline Factor 10 & Safety and Security in the Destination & 0.584 \\
\hline Factor 11 & Fear of Language & 0.554 \\
\hline
\end{tabular}

Table 15: Ranked Mean Value of Factor Variables

\begin{tabular}{|l|l|c|}
\hline Rank & Factor Name & Mean Value \\
\hline 1 & Safety of Belongings & 0.846 \\
\hline 2 & Health Precautions & 0.805 \\
\hline 3 & New Experience & 0.715 \\
\hline 4 & Exploring New Things & 0.713 \\
\hline 5 & Comfort and Well-Being & 0.710 \\
\hline 6 & Influence of Family and Friends & 0.694 \\
\hline 7 & Thrilling Experience & 0.678 \\
\hline 8 & Learning and Involvement & 0.677 \\
\hline 9 & Confidence in Communication & 0.666 \\
\hline 10 & Safety and Security in the Destination & 0.584 \\
\hline 11 & Fear of Language & 0.554 \\
\hline
\end{tabular}

Of all the Factors identified, it was found that the respondents were most concerned about the safety of their belongings (0.846), followed by a safety on their health $(0.805)$. Respondents were also eager to explore new experiences (0.715) and new things (0.713) while on holiday in a destination.

Respondents were also concerned about their comfort in the destination where they were holidaying in (0.710). The influence of Family and Friends did not feature prominently while choosing a holiday destination (0.694). Respondents wanted thrills (0.678), learning and enjoyment (0.677) to be part of their holiday. 
Communication (0.677) and Language (0.554) ranked the least while on holiday to a destination.

\section{Conclusion}

The study found that tourists from South India perceived maximum risk when it involved the safety of their belongings during their travel. Most of the tourists preferred carrying heavy luggage during their travel but most of them were afraid of losing or misplacing their belongings during travel.

Tourists from South India were always concerned about their safety and their health during travel. They were afraid of falling sick from having the local food and water during travel, and therefore they never left for a vacation without carrying their medicines and first aid; Tourists also preferred to travel in the most comfortable mode during a holiday.

It was found that tourists always looked forward to experiencing something totally new during a holiday, from what they had already experienced before. Surprisingly, tourists from South India did not plan their holidays in much detail as they felt that it took away a lot of unexpectedness in the destinations. The tourists preferred holidays that were educational as cultures and customs very different from their own always attracted them. During holidays, tourists always looked forward to changes in the environment, as the same routine bored them.

Learning and involvement formed an integral part of the holiday experience of South Indian tourists. They showed great interest in interacting with the local community and they made sure that they spent time reading and studying about the culture of the destinations that they planned to visit; They always wanted a sense of discovery to be part of their holidays and they liked to take a holiday from time to time as it helped them to unwind.

Tourists from South India always made sure that they were comfortable with the holiday destinations that they chose and they always looked forward to enhancing their feeling of well-being during a holiday. The tourists never travelled to destinations unless they were confident about the safety of the destinations. 
Family and friends have a significant impact on the choice of holiday destinations. Many times, tourists feared that family and friends could disapprove of their choice of holiday destinations; Tourists felt safe traveling to destinations because everyone else went there and they wanted to travel to holiday destinations to enhance their self-image among their family and friends; Tourists from South India were also afraid that they might end up spending a lot of money during travel. They believed that more time spent on a holiday would make it more pleasurable and enjoyable.

Tourists also looked forward to thrilling experiences during holidays. They felt good being a little scared during a holiday which made them indulge in frightening, thrilling and daring activities during the holidays; They enjoyed experiencing surprises during the holiday and looked forward to seeking adventures during the vacation.

Confidence in communicating in the destinations was another important factor that influenced the choice of holiday destinations. Tourists from South India were assured of communicating confidently with anyone during a holiday. They extensively used telecommunication devices during holidays and they preferred to always carry and use their smartphones during holidays. Tourists also felt that their knowledge in the English language would help them in communicating successfully in different cultures. Language barriers did not prevent them from holidaying in unknown destinations.

Safety and security of tourists also influence their choice of holiday destinations. Anxiety about safety and security always prevented them from taking risks during travel, and local news about destinations influenced their holidays there. Civil unrest demotivated tourists from travelling to destinations, but they did not mind travelling to destinations that were politically unstable.

The study was able to develop an understanding of the dimensions of perceived risk experienced by tourists from South India. Numerous factors of perceived risk were identified and discussed through the study. Perceived risks varied according to the nature of 
the destination and it was this overall perception of risk that influenced the tourists' choice of holiday destinations.

\section{Literatures Reviewed}

Ankomah, P. K., Crompton, J., \& Baker, D. (1996). Influence of cognitive distance in vacation choice. Annals of Tourism Research, 23(1), 138-150.

Bauer, R. (1967). Consumer behavior as risk taking. In D. Cox (Ed.), Risk taking and information handling in consumer behavior. 23 - 33. Cambridge: Harvard University Press.

Brooker, G. (1984). An assessment of an expanded measure of perceived risk. Advances in Consumer Research, 11, 439-441.

Chandler, J. A., \& Costello, C. A. (2002). A Profile of Visitors at Heritage Tourism Destinations in East Tenessee according to Plog's Lifestyle and Activity Level Preferences Model. Journal of Travel Research, 41, 161-166.

Cohen, E., \& Cooper, R. L. (1986). Language and Tourism. Annals of Tourism Research, 13, 533-563.

Dowling, G. R., \&Staelin, R. (1994). A Model of Perceived Risk and Intended Risk-handling Activity. Journal of Consumer Research, 21, 119-134.

Fletcher, J., \& Morakabati, Y. (2008). Tourism activity, terrorism and political instability within the commonwealth: the cases of Fiji and Kenya. International Journal of Tourism Research, 10(6), $537-556$.

Hofstede, G. (1983). The cultural relativity of organizational practices and theories. Journal of International Business Studies, 14(2), 75 - 89.

Hofstede, G. (1984). Culture's consequences: International Differences in Work-Related Values. Beverly Hills, California: Sage Publications, Inc.

Hofstede, G. (2001). Culture's consequences: Comparing values, behaviors, institutions, and organizations across nations (2nd ed.). Thousand Oaks, California: Sage Publications, Inc.

Jacoby, J., \& Kaplan, L. (1972). The components of risk perception.

In M. Venkatesan (Ed.), Proceedings of the 3rd annual conference (pp. 382 - 393). Champaign: Association for Consumer Research. 
Kaplan, L., Szybillo, G., \& Jacoby, J. (1974). Components of perceived risk in product purchase: a cross-validation. Journal of Applied Psychology, 59(3), 287 - 291.

Laroche, M., McDougall, G. H. G., Bergeron, J., \& Yang, Z. (2004). Exploring How Intangibility Affects Perceived Risk. Journal of Service Research, 6(4), 373-389.

Lepp, A., \& Gibson, H. (2003). Tourist roles, perceived risk and international tourism. Annals of Tourism Research, 30(3), 606-624.

Mitra, K., Reiss, C., \& Capella, L. (1999). An examination of perceived risk, information search and behavioral intentions in search, experience and credences services. Journal of Services Marketing, 13(3), 208 - 226.

Mazursky, D. (1989). Past experience and future tourism decisions. Annals of Tourism Research, 16, 333-344.

Mitchell, V.-W., Davies, F., Moutinho, L., \& Vassos, V. (1999). Using Neural Networks to Understand Service Risk in the Holiday Product. Journal of Business Research, 46, 167-180.

Moutinho, L. (1987). Consumer behavior in tourism. European Journal of Marketing, 21(10), 5-44.

Nickerson, N. P., \& Ellis, G., D. (1991). Traveller Types and Activation Theory: A Comparison of Two Models. Journal of Travel Research (Winter), 26-31.

Peter, J. P., \& Ryan, M. J. (1976). An Investigation of Perceived Risk at the Brand Level. Journal of Marketing Research, 13, 184-188.

Plog, S. (1994). Developing and Using Psychographics in Tourism Research. In J. R. B. Ritchie \& C. R. Goeldner (Eds.), Travel, Tourism, and Hospitality Research: a handbook for managers and researchers (2nd ed.): John Wiley \& Sons, Inc

Richter, L. K. (2003). International Tourism and Its Global Public Health Consequences. Journal of Travel Research, 41, 340-347.

Reisinger, Y., \& Mavondo, F. (2005). Travel anxiety and intentions to travel internationally:

Implications of travel risk perception. Journal of Travel Research, 43(3), 212 - 225.

Roehl, W. S., \& Fesenmaier, D. R. (1992). Risk Perceptions and

Pleasure Travel: An Exploratory Analysis. Journal of Travel Research, 17-26. 
Sonmez, S., \& Graefe, A. (1998a). Influence of terrorism risk on foreign tourism decisions. Annals of Tourism Research, 25(1), 112 $-144$.

Stone, R. N., \& Gronhaug, K. (1993). Perceived Risk: Further Considerations for the Marketing Discipline. European Journal of Marketing, 27(3), 39-50.

Woodside, A. G., \& Lysonski, S. (1989). A General Model of Traveler Destination Choice. Journal of Travel Research, 27(4), 814. 